\title{
The Role of the Kidney in the Elimination of Pancreatic Lipase and Amylase from Blood ${ }^{1}$ )
}

\author{
By W. Junge
}

Zentrallaboratorium des Städtischen Krankenhauses und der II. Med. Klinik der Universität Kiel, Kiel

\author{
M. Mályusz and H.J. Ehrens
}

Physiologisches Institut der Universität Kiel, Kiel

(Received July 11, 1984/March 20/April 24, 1985)

Summary: Two clinical observations indicate that the kidney plays the main role in the elimination of lipase and amylase from the circulation:

1. in patients with uncomplicated acute pancreatitis the decrease of the activity of both enzymes in the serum ran almost in parallel. The half life for lipase was found to be $6.9-13.7 \mathrm{~h}$, and somewhat higher figures $(9.3-17.7 \mathrm{~h})$ were calculated for amylase;

2. in patients with reduced glomerular filtration rate the serum activity of either or of both enzymes was distinctly elevated.

The contribution of the kidney to the elimination of lipase and amylase from blood was studied in the rat. After an intravenous bolus injection of homologous lipase and amylase, the serum activity of both enzymes decreased rapidly. The half-life of lipase was $18.1 \mathrm{~min}$, that of amylase $20.5 \mathrm{~min}$. Up to $30 \%$ of the injected amylase but only traces of lipase activity were recovered in the urine. In animals with ligated kidneys the serum half-life of both enzymes was 3 times longer.

Our results indicate that lipase as well as amylase are removed from the serum mainly by glomerular filtration at nearly the same rate. Reabsorption of lipase is almost complete, in contrast to that of amylase. It is suggested that the differences in the renal handling of both enzymes are due to their differing affinities for hydrophilic and hydrophobic surfaces.

\section{Die Bedeutung der Niere für die Ausscheidung von Pankreaslipase und-amylase aus dem Blut}

Zusammenfassung: Zwei klinische Beobachtungen deuten darauf hin, daß der Niere die Hauptrolle bei der Elimination von Lipase und Amylase aus der Zirkulation zukommt.

1. Bei Patienten mit unkomplizierter akuter Pankreatitis findet sich ein parallel verlaufender Abfall beider Enzymaktivitäten. Die Halbwertszeit für die Lipase liegt zwischen 6,9 bis $13,7 \mathrm{~h}$, für die Amylase ergaben sich etwas höhere Werte mit 9,3 bis $17,7 \mathrm{~h}$.

2. Die Mehrzahl von Patienten mit deutlich eingeschänkter glomerulärer Filtrationsrate hatte erhöhte Serumaktivitäten beider oder eines von beiden Enzymen.

Tierexperimentell wurde die Rolle der Niere bei der Ausscheidung von Lipase und Amylase aus dem Blutkreislauf an Ratten näher untersucht. Nach einer intravenösen Bolus-Injektion der beiden homologen

1) Excerpts of this paper have been presented to the 5th European Congress of Clinical Chemistry, Budapest, 1983. 
Enzyme fand sich ein rascher Abfall der Enzymaktivitäten mit einer Halbwertszeit von 18,1 min für die Lipase und von 20,5 min für die Amylase. Während von der gegebenen Amylasedosis etwa $30 \%$ in aktiver Form im Urin erschien, ließen sich von der Lipase nur initial Spuren nachweisen. Bei Tieren mit abgebundenen Nieren ergaben sich um den Faktor 3 längere Halbwertszeiten für beide Enzyme.

Unsere Ergebnisse zeigen, daß Lipase und Amylase in etwa gleichem Ausmaß durch glomeruläre Filtration aus der Zirkulation ausgeschieden werden, daß Lipase aber im Gegensatz zu Amylase praktisch vollständig von der Niere rückresorbiert wird. Dieser Unterschied in der renalen Behandlung beider Enzyme könnte mit deren unterschiedlicher Affinität zu hydrophilen bzw. hydrophoben Oberflächen zusammenhängen.

\section{Introduction}

The fate of proteins released into the circulation irrespective of whether they are secreted or liberated from injured cells - is to a large extent unknown (for review see l.c. (1)). The mechanism of removal is clarified only for small proteins $\left(M_{\mathrm{r}} 60000\right)$. These are more or less quantitatively eliminated from the blood by glomerular filtration, as shown, for example, for polypeptide hormones or free light chains of immunoglobulins in myeloma. The same seems also to apply to amylase $\left(M_{\mathrm{r}} 54000\right)$. Shortly after the onset of an acute pancreatic disorder, active amylase appears in the urine. Measurement of urinary amylase activity is therefore a valuable tool for the laboratory diagnosis and monitoring of pancreatitis. In healthy subjects clearance of amylase amounts to about $2 \%$ of the creatinine clearance, but in acute pancreatitis it may even reach $10-15 \%$.

In contrast to amylase, little is known about the elimination of pancreatic lipase from the circulation. This enzyme has an even smaller molecular weight than amylase $\left(M_{\mathrm{r}} 48.000\right)$, thus it could be expected to be filtered in the kidney. However, reports concerning the detection of lipase activity in the urine are contradictory $(2,3,4)$. Traces of the enzyme have been detected in urine by an immunological technique but only in amounts masked by the physiological proteinuria (5).

While the exact knowledge of the mechanism of elimination of intravascular enzymes is of little diagnostic relevance, the knowledge of the rate of their disappearance is important: a delayed fall of the serum activity indicates persistence or even progress of a pathological process. The half lives of most of the diagnostically useful enzymes have been empirically determined in patients with a severe, short-lasting tissue injury. However, reliable data for amylase obtained in this way are scarce: Nord et al. found a half-life of $10 \mathrm{~h}$ for amylase in man after intravenous administration of the enzyme (6). For lipase there is only one single clinical observation available which shows a half-life of $15 \mathrm{~h}$ (7).
It was therefore the aim of the present study to determine

a) the half-life for both pancreatic lipase and amylase, and

b) to elucidate the role of the kidneys in the elimination of these enzymes.

Our study was carried out in patients with uncomplicated acute pancreatitis without impaired renal function as well as in patients without pancreatic disorders but suffering from severe renal insufficiency. Furthermore, in order to study the immediate effect of the kidney on the elimination of lipase and amylase, experiments employing purified amylase and lipase were performed in healthy rats.

\section{Materials and Methods}

Patients

Several subjects were selected from a group of more than a hundred patients admitted to our hospital with acute pancreatitis. They had in common very high initial serum lipase and amylase activities, and were therefore closely monitored: routine laboratory parameters and serum enzyme activities were checked at least every 12 hours. The second group studied consisted of patients maintained on haemodialysis due to chronic renal insufficiency. They had no known pancreatic disorders.

\section{Animal experiments}

Albino Wistar rats of $200-300 \mathrm{~g}$ body weight maintained on normal laboratory chow (Altromin 1321R) were used. The animals were narcotized with pentobarbital (Nembutal $\left.{ }^{\otimes}\right)$ (40 $\mathrm{mg} / \mathrm{kg}$ body weight) injected intraperitoneally. As described previously (8), a polyethylene catheter was placed into one of the external jugular veins and a continuous infusion of physiological saline was started $(1.2 \mathrm{ml}$ per hour $)$ in order to secure sufficient diuresis. This was followed by opening the abdomen by a mid-line incision and cannulation of both ureters with polyethylene catheters (Intramedic PE 10, Clay Adams, USA). The abdomen was closed by $2-3$ sutures. After $30 \mathrm{~min}$, rat pancreatic extract (see below) was administered in a single dose through the venous catheter. In several experiments this dose also contained $\left[{ }^{14} \mathrm{C}\right]$ labelled inulin. Some of the animals received a continuous inulin infusion in order to check the glomerular filtration rate (GFR). 
In experiments on nephrectomized animals the kidneys were ligated prior to the injection of the pancreatic extract. These animals received no continuous infusion.

Blood samples $(60 \mu \mathrm{l})$ were collected from the tail every $10 \mathrm{~min}$, starting $5 \mathrm{~min}$ after injection. Sampling was carried out for 120 $\min$.

Urine samples were collected from both kidneys. The sampling periods varied between 10 and $30 \mathrm{~min}$, according to the diuresis. At the end of the collecting period the abdomen was reopened and the animal was exsanguinated by drawing blood from the abdominal aorta.

\section{Preparative methods}

Rat pancreatic extract was obtained as follows: pancreatic tissue was homogenized with an Ultraturrax homogenizer (Janke and Kunkel, FRG) at top speed for $2 \mathrm{~min}$ in a twentyfold volume of distilled water containing soy-bean trypsin inhibitor $(1 \mathrm{~g} / \mathrm{l})$. To the homogenate an equal volume of Frigen ${ }^{*}$ (tri-chloro-tri-fluoro-ethane) was added. After thorough (end over end) mixing for $10 \mathrm{~min}$ the preparation was centrifuged at $8000 \mathrm{~g}$. The clear supernatant was lyophilized and resuspended in $0.15 \mathrm{~mol} / 1 \mathrm{NaCl}$ so that $1 \mathrm{ml}$ of the suspension corresponded to the extract of $1 \mathrm{~g}$ tissue. After dialysis against $0.15 \mathrm{~mol} / \mathrm{l} \mathrm{NaCl}$ for $2 \mathrm{~h}$ the preparation was frozen at $-20^{\circ} \mathrm{C}$. Lipase activity of the preparation exceeded $750000 \mathrm{U} / 1$, amylase activity $250000 \mathrm{U} / \mathrm{l}$.

\section{Analytical methods}

Measurement of the lipase catalytic activity of all samples was carried out using a Boehringer kit (Monotest ${ }^{\star}$ Lipase No 159697) without modification (turbidimetric method). For the determination of amylase activity the continuous UV test of Biomed, FRG employing maltotetraose as substrate (Monamylneu) was used. Creatinine was determined by the Jaffé reaction using an Auto Analyzer II. Activity of $\left[{ }^{14} \mathrm{C}\right]$ inulin was measured in a liquid scintillation spectrometer (Packard Tri-Carb 300 CD).

\section{Calculations}

Biological half-life $\left(\mathrm{t}^{1} / 2\right)$ for all substances tested was calculated from the blood samples by computing the least squares linear regression. For better comparison the injected activity was set at $100 \%$ in every experiment. Symbols in the respective figures represent the mean value $(x)$ and the standard deviation (SD) for each sampling period. The renal clearance (C) of $\left[{ }^{14} \mathrm{C}\right]$ inulin was calculated using the classical clearance formula. Total and renal clearance as well as their difference (extrarenal clearance) of both lipase and amylase were computed on the basis of the formula for single injection technique (9). The results are related to $100 \mathrm{~g}$ body weight.

Statistical analyses were carried out using the Student $\mathrm{t}$ test. Mean values $(\overline{\mathbf{x}})$, standard deviation (SD) and the number of experiments (n) are given. Differences between the half-life of lipase and amylase in the same animal were determined using the paired $t$ test. The mean difference (d) and the corresponding $t$ paired are given. Any deviation was considered significant if the requirement $\dot{p}<0.05$ was fulfilled.

\section{Results}

In figure 1 the decrease of lipase and amylase catalytic activity in serum is shown in three patients with acute pancreatitis. In all three cases there was no large variation in the apparent half-life of the enzymes studied (shortest $\mathrm{t}^{1} / 2$ : lipase, $6.9 \mathrm{~h}$ : longest: amylase,
$17.7 \mathrm{~h}$ ). In all patients amylase had a somewhat longer $\mathrm{t}^{1} / 2$ than lipase (by about $23 \%$ ). Similar results were obtained in two further patients (not shown here).

Figure 2 shows the plasma lipase and amylase concentration of 28 patients with severe renal insufficiency. 15 of them had a higher than normal plasma lipase concentration (left panel); the amylase concentration exceeded the upper limit of the normal range in 10 cases (right panel). There was no correlation between serum enzyme activity and serum creatinine concentration.

The elimination rate of lipase and amylase from the plasma of rats is demonstrated in figure 3 . In animals

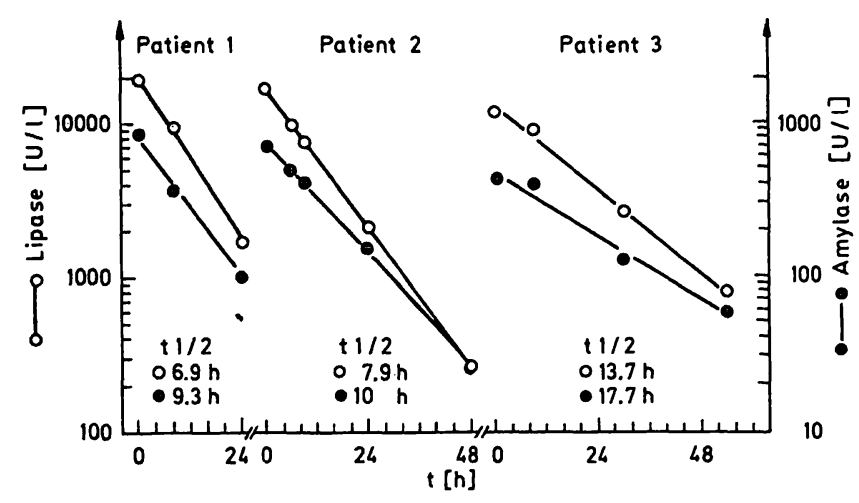

Fig. 1. Elimination rate of lipase and amylase in three patients with acute pancreatitis.

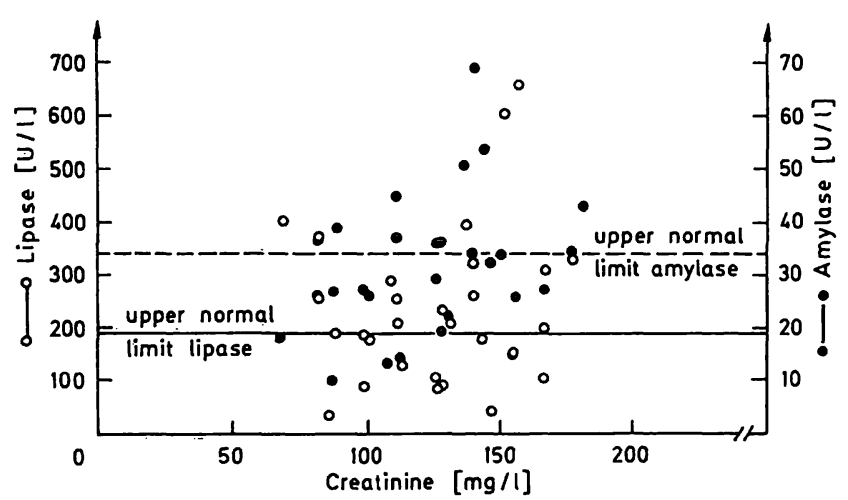

Fig. 2. Serum lipase and amylase activity in relation to plasma creatinine concentration in 28 patients with renal insufficiency.

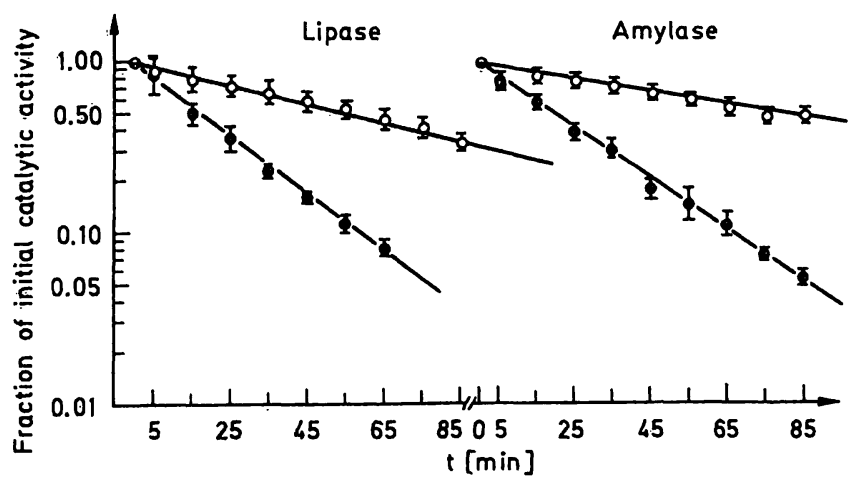

Fig. 3. Elimination rate of lipase and amylase in rats with normal renal function $(0)$ and with ligated kidneys $(0)$. $\mathrm{n}=4$. 
with unimpaired renal function (full dots) $t^{1 / 2}$ of lipase was $18.1+2.2 \mathrm{~min}, \mathrm{n}=4$. It differed significantly from that of amylase $(20.5+2.0 \mathrm{~min})$; $\mathrm{d}=2,4 \mathrm{~min}, \mathrm{t}=8.66$. Regression coefficient $(\mathrm{r})$ was 0.99 in both cases. Open circles demonstrate the plasma enzyme activities in rats with ligated kidneys. The slope of the regression lines of both lipase and amylase differs significantly from those in animals with functioning kidneys. The deviation is significant. At the same time $t^{1 / 2}$ of lipase $(55.6+9.2 \mathrm{~min}$, $\mathrm{n}=4$ ) was significantly shorter than $\mathrm{t}^{1 / 2}$ of amylase $(79.6+10.4 \mathrm{~min}) ; \mathrm{d}=24.3 \mathrm{~min}, \mathrm{t}=10.6$.

Serum $\left[{ }^{14} \mathrm{C}\right]$ inulin radioactivity decreased according to the first-order equation: $\ln \mathrm{y}=-0.00236 \mathrm{x}+$ 4.584, $\mathrm{r}=0.99$. Half-life of $\left[{ }^{14} \mathrm{C}\right]$ inulin in control rats was equal to $29.4+1.8 \min (n=4)$.

Figure 4 shows the urinary recovery of lipase and amylase in two typical experiments. There was only a little excretion of lipase during the first $40 \mathrm{~min}$. While the total excreted activity remained well below $5 \%$ of the injected activity, amylase was excreted continuously by the kidneys up to $30 \%$ of the given dose.

Table 1 contains the data of the clearance of lipase and amylase. It is evident that the clearance of lipase (total as well as renal) exceeded the clearance of amylase significantly. The clearance of $\left[{ }^{14} \mathrm{C}\right]$ inulin was $0.42+0.03 \mathrm{ml} / \mathrm{min} \times 100 \mathrm{~g}$ body weight $(\mathrm{n}=16)$.

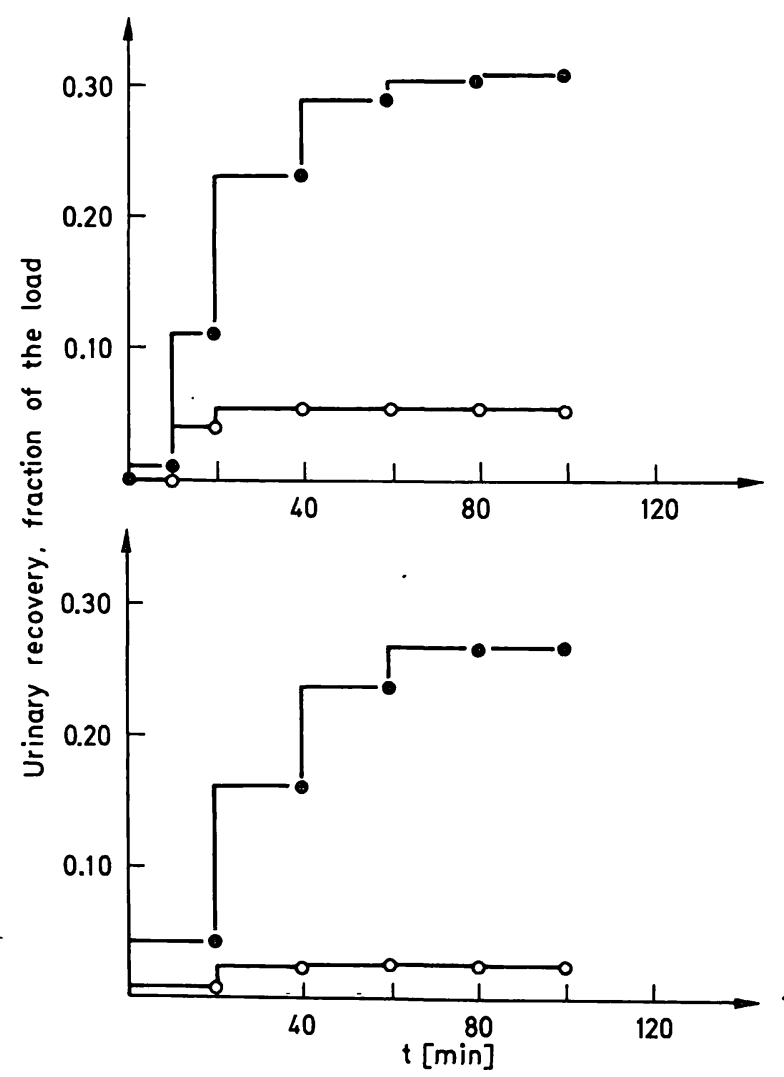

Fig. 4. Urinary recovery of the injected lipase and amylase activity in two rats. $0=$ lipase; $\bullet=$ amylase.
Tab. 1. Clearance of lipase and amylase in the rat $(\mathrm{ml} / \mathrm{min} \times$ $100 \mathrm{~g}$ body weight).

\begin{tabular}{|c|c|c|c|}
\hline \multirow[t]{2}{*}{ Clearance } & \multicolumn{2}{|l|}{ Lipase } & Amylase \\
\hline & SD & $\mathrm{n}=7$ & SD \\
\hline Total & $0.225 \pm 0.019$ & & $0.184 \pm 0.020^{*}$ \\
\hline Renal & $0.159 \pm 0.016$ & is & $0.134 \pm 0.010^{*}$ \\
\hline Extrarenal & $0.066 \pm 0.007$ & & $0.049 \pm 0.006^{*}$ \\
\hline
\end{tabular}

* = significant deviation from lipase

\section{Discussion}

Our study demonstrates that in cases of uncomplicated, monophasic pancreatitis pancreatic lipase and amylase disappear rapidly from the circulation at approximately the same rate (fig. 1). The elimination kinetics are first order, which implies that in these patients a severe, but single and rather shortlasting pathological event occured. It is probable that the enzymes released into the circulation in acute pancreatic disorders enter the intravascular compartment via the thoracic duct (10). Therefore, if the period of enzyme release is short and the peripancreatic lymphflow is unimpaired, the situation in patients is similar to our experimental design in rats, i.e. to a bolus injection. The lowest $t / 1 / 2$ values found for both enzymes $(6.9 \mathrm{~h}$ for lipase and $9.3 \mathrm{~h}$ for amylase - fig. 1) are distinctly lower than those for most other clinically important enzymes. This finding is relevant to the problem of clinical diagnosis; repeated checks of the lipase and amylase activity of the serum make it possible to monitor within hours whether or not the underlying pathological process still persists and what course the disease takes. Thus, in uncomplicated, acute pancreatitis, usually of the oedematous type, a rapid fall of the serum activity can be expected. In diseases with persisting tissue breakdown, e.g. alcoholic (toxic) pancreatitis, an eventual initial rapid decline would be followed by consistently high serum activities. It can therefore be concluded that a long-lasting hyperlipasaemia is either due to progressive tissue damage or to the development of pancreatic pseudocysts. Gel filtration experiments showed no indication for the presence of high molecular weight forms of lipase in pancreatitis sera (own, unpublished results), thus a delayed elimination caused by binding of the enzyme to serum lipoproteins (11) seems not to occur.

Our results show that the elevated levels of lipase, amylase and creatinine in the serum of patients with severe renal insufficiency (fig. 2) are caused by a 
decreased GFR rather than by an increased enzyme liberation from the pancreas due to an undefined "uraemic pancreatitis", as suggested by some authors $(12-14)$. In this context the lack of any correlation between enzyme activity and creatinine concentration of the serum is not surprising.

The clinical observation that lipase and amylase are rapidly eliminated from the serum at nearly the same rate is supported by our experimental data obtained in rats (fig. 3). The small, but statistically significant difference in the half-life of both enzymes corresponds to the difference between their respective molecular weights (see above). The elimination shows first order kinetics in both cases with no indication for a biphasic course. The rate of renal elimination of these enzymes from serum is fast. It greatly exceeds even the summary effect of other possible factors that would lead to a decline in serum activity (distribution into other compartments, or degradation).

These results are in contrast to the basic concept on the distribution of intravenously administered enzymes as suggested by Friedel et al. (15). These authors determined the elimination rates of several enzymes of diagnostic importance. Their experimental design was similar to the methods used in the present investigation. They found a linear, log$\log$ relationship between the rate of distribution into the interstitial compartment and the molecular weight of the enzymes studied. Introducing the molecular weights of lipase and amylase into their experimentally determined equation (ln molecular weight $\left.=0.532 \cdot \ln t^{1} / 2+9.54\right)$ results in half-lives insignificantly lower than those determined by us: 10.3 and $13.3 \mathrm{~min}$ versus 18.2 and $20.5 \mathrm{~min}$, respectively. However, in animals with ligated kidneys the half-lives were far longer than was expected from the data of Friedel et al. (15), (fig. 4). This contradiction can be explained by the fact that the distribution/elimination curve(s) proposed by the above authors were obtained in animals with functioning kidneys. Nevertheless, they disregarded renal effects in the elimination process. This might be acceptable as long as only proteins with à $M_{\mathrm{r}}>60000$ are concerned. It can certainly not be applied to filterable molecules in the range of size of lipase and amylase.
The excretion rate of both lipase and amylase distinctly exceeded their respective distribution rate (fig. 3, 4, tab. 1). Moreover, the elimination rate of both enzymes was even larger than that of inulin. The latter is completely filterable and diffuses into the interstitial space readily. This indicates that with normal kidney function an extravasal equilibrium will not be achieved in practice for either enzyme (see above). Thus, general formulas (15) for the calculation of distribution and/or elimination rates are helpful only if they are based on experiments carried out on animals with ligated, as well as with functioning kidneys. Evidence for the renal filtration of lipase, as well as for albumin and $\beta_{2}$-microglobulin, has recently been presented in an experiment in humans after inhibition of tubular reabsorption by lysine (16).

The different handling of lipase and amylase by the kidney (fig. 4, tab. 1) is a further example for the known selectivity of protein reabsorption in the renal tubular system (17). Experimental data indicate that the net charge of proteins might be of importance (18). However, these data were obtained with cationic proteins, e. g. lysozyme and cytochrome c (19). Therefore the idea that several proteins in the renal tubule are absorbed to the negatively charged luminal membrane is certainly attractive. On the other hand the majority of filtered serum proteins, including lipase and amylase, carry a negative net charge at physiological $\mathrm{pH}$. Thus, the charge factor is obviously of minor significance. Since both enzymes have practically the same size and a similar net charge (IP for lipase $=5.8(20)$; IP for the different forms of amylase $=6.5-7.1(21)$ ) other or additional factors must be responsible for the marked difference in the extent of their tubular uptake. Differences in the physicochemical properties of lipase and amylase seem to us to be a more likely cause of their different renal behaviour. Amylase has a high affinity towards hydrophilic sites (starch, glycogen), whereas lipase has a high affinity for hydrophobic surfaces or for lipophilic-hydrophilic interfaces. Therefore, it is conceivable that these different properties are relevant to the binding and uptake by the luminal membrane. However, as yet no experimental data supporting this idea can be presented.

\section{References}

1. Friedel, W. R., Diederichs, F. \& Lindena, J. (1979) Release and extracellular turnover of cellular enzymes. In: Advances in clinical enzymology (Schmidt, E., Schmidt, F. W., Trautschold, I. \& Friedel, R., eds.) pp. 70-105, S. Karger, Basel.

2. Appel, W. \& Scholz, H.-G. (1977) J. Clin. Chem. Clin. Biochem. 15, 339-343.

3. Rick, W. (1976) Messung von Enzymaktivitäten. In: Handbuch der inneren Medizin, 5. Aun., Band 3, Teil 6, Pankreas (Forell, M. M., ed.) pp. 326-368, SpringerVerlag, Berlin, Heidelberg.

4. Ehara, K. (1981) Med. Technology 30, 592-595.

5. Hoffmann, G., Junge, W., Schmidt, D., Weiss, L. \& Hoffmann, S. (1984) Ärztl. Lab. 30, 193-196. 
6. Nord, H. J., Weis, H. J. \& Cölle, H. (1973) Verh. Dtsch. Ges. Inn. Med. 79, 868-870.

7. Rick, W. (1968) In: Praktische Enzymologie (Schmidt, E., ed.) p. 159, Huber, Bern.

8. Mályusz, M.. Mendoza-Osorio, V. \& Ochwadt, B. (1972) Pflügers Arch. 332, 28-33.

9. Levinsky, N. G., Levy, M. (1973) Clearance techniques. In: Handbook of Physiology, Section 8, Renal Physiology (Orloff, J. \& Berliner, W. R., eds.) pp. 103-117, American Physiological Society, Washington D.C.

10. Wanke, M. (1976) Pathogenese und morphologisches Bild akuter Pankreas-Erkrankungen. In: Handbuch der inneren Medizin. 5. Aufl., Band 3, Teil 6, Pankreas (Forell, M. M., ed.) pp. 519-615, Springer, Berlin.

11. Lawrence, S. H. \& Melnik, P. J. (1961) Proc. Soc., Exp. Biol. Med. 107, 998-1001.

12. Otte, M., Stahlheber, H., Forell, M. M., Dobbelstein, H., Richert, J., Thurmayr, R. \& Thurmayr, G. R. (1975) Klin. Wochenschr. 53, 67-72.
13. Wittich, K. A., Schmidt, H., Scheler, F. \& Creutzfeldt, W, (1968) Verh. Dtsch. Ges. Inn. Med. 74, 1072-1074.

14. Goebell, H. (1970) Internist $11,117-122$.

15. Friedel, R., Bode, R. \& Trautschold, I. (1976) J. Clin. Chem. Clin. Biochem. 14, 129-136.

16. Moller-Petersen, J., Dati, F. (1984) Clin. Chem. 30, $343-344$.

17. Maunsbach, A. B. (1976) In: Kidney and Urinary Physiology II (Thurau, K., ed.) University Park Press, Baltimore, p. $145-167$.

18. Maack, T. (1975) Amer. J. Med. 58, 57-64.

19. Sumpio, B. E. \& Maack, T. (1982) Amer. J. Physiol. 243 (Renal Fluid Electrolyte Physiol. 12) F379-F392.

20. De Caro, A., Figarella, C., Amic, J., Michel, R. \& Guy, O. (1977) Biochim. Biophys. Acta 490, 411-419.

21. Armstrong, M. L. (1976) Postgrad. Med. J. 52, 456-466.

Priv.-Doz. Dr. W. Junge

Jägersberg 7-9

D-2300 Kiel 